А. Г. Малыгин преподаватель

\title{
ВЫБОР СТРАНОВЕДЧЕСКИХ ТЕМ И СОДЕРЖАНИЯ УРОКА ПРИ ОБУЧЕНИИ АНГЛИЙСКОМУ ЯЗЫКУ КАК ВТОРОЙ СПЕЦИАЛЬНОСТИ НА I-II КУРСАХ ПЕДАГОГИЧЕСКИХ УНИВЕРСИТЕТОВ
}

У статті обтрунтовано важливість правильного вибору тем і краӥнознавчого матеріалу для занять з англійської мови на I-II курсах філологічних факультетів. Визначено дидактичні умови реалізачії міжкультурних факторів, які треба враховувати при викладанні іноземної мови.

Современные направления в преподавании иностранных языков в высшей школе ориентированы не только на усвоение учащимися определенного количества языковых единиц и форм, на развитие у студентов речевых умений (говорить, аудировать, читать и писать), но и на расширение общих знаний о странах изучаемого языка, их географии, экономике, особенностях политической системы. Поэтому мы считаем, что на занятиях по 
английскому языку для студентов-филологов, которые изучают английский язык в качестве второй специальности, необходимо вводить новые интерактивные методики, новые современные тексты для чтения и анализа, новые темы и повседневные ситуации. Следует также шире использовать видеоматериалы, ресурсы Интернета и т. д.

Доминирование грамматической прогрессии и «повседневной ситуации» в планировании преподавания английского языка часто делают второстепенными тексты учебников. Темы и ситуации служат в начальном обучении почти только для «упаковки» грамматического и словарного материала. Новые темы преподносятся в виде правильного диалога, и студент должен этот диалог-модель выучить наизусть и воспроизвести. Семнадцати-восемнадцатилетние студенты имеют слабую мотивацию, если при изучении иностранного языка как второй специальности они еще раз будут разыгрывать все те же тематические отрывки. Ведь они вовлекаются в ролевые игры, которые, возможно, волновали и были важными во время занятий родным языком в детском возрасте (назвать части тела, назвать и «купить» предметы одежды и т. д.).

То, что могло бы заинтересовать студентов на уроке английского языка, нам представляется несколько иным - это возможность ознакомиться с чужим, в нашем случае с англоязычным миром, и сравнить его с собственным. Темы, которые с педагогической точки зрения являются осмысленными, служат расширению жизненного опыта студентов. Нужно использовать такую тематическую работу, которая давала бы возможность познакомиться с англоязычными странами, побуждая использовать собственный жизненный опыт для сравнения своего и чужого миров.

Откуда, по вашему мнению, наши студенты черпают в первую очередь информацию об Англии, Америке и о других англоязычных странах? Это телевидение, пресса, урок английского языка, другие уроки, родители, туристы, волонтеры Корпуса Мира США, фирмы, где делопроизводство ведется на английском языке.

Насколько «здоровыми» выглядят знания об этих странах? (Политика, спорт, музыка, литература, история, повседневный мир, поп культура?)

Информация о зарубежных странах всегда фрагментарна. Какие стереотипные представления имеются в нашей стране об англичанах, американцах, канадцах, других представителях англоязычного мира? Чем они обусловлены?

Столкновение с чужим миром протекает на фоне определенного жизненного опыта студента или фрагментарных знаний о чужом мире. Их влияние на самосознание учащегося может простираться от восхищения чужим и девальвации собственного мира до определенного отказа от «иностранного» (культурный шок). Следовательно, необходимо действовать очень осторожно при выборе тем. 
Очень важно, чтобы темы выбирались и составлялись таким образом, чтобы студент находил осмысленные точки соприкосновения с собственным жизненным опытом. Он должен во время «экскурсии в чужой мир» иметь надежную опору в собственном культурном опыте, одновременно ему должно быть предложено столько много нового о чужом мире, чтобы его любопытство было возбуждено (мотивация учиться дальше!), но не сводилось к наивному «восхищению» чужим миром. Поэтому, если необходимо, такие процессы понимания и изучения на уроке всегда обсуждаются на родном языке.

Таким образом, при выборе страноведческих тем для урока английского языка не следует исходить только из перспективы «что необходимо знать о стране изучаемого языка» или основываться на собственном культурном жизненном опыте.

Мы, преподаватели, должны научиться видеть англоязычный мир глазами учеников, в противном случае существует опасность «прививания» им знаний, которые им не нужны, или они будут сбиты с толку, получив определенную, но «ненужную» информацию.

С другой стороны, необходимо быть осторожным при выборе незначительных отдельных аспектов, поскольку студенты не знакомы со шкалой для их правильной классификации и определенно склоняются к обобщениям отдельных фактов.

Как можно выбрать такие темы, которые были бы рациональны с педагогической точки зрения, представляли бы интерес для студентов и одновременно неискаженно показывали бы действительность стран изучаемого языка?

Прежде всего, представляется разумным опросить самих студентов, что их интересует, какие темы они хотели бы обсудить на уроке английского языка.

Конечно, подобный опрос имеет только ограниченное значение при выборе тем. Интересы ученика меняются и обусловлены развитием и возрастом. Они меняются также внутри сферы культуры по мере изменения ориентиров, присущих данному обществу.

Есть еще одна возможность - подобрать такие темы и вопросы, которыми особенно интересуются их ровесники в англоязычных странах. Но эти темы быстро меняются в соответствии с переменами в странах изучаемого языка, а также теми переменами, которые происходят в нашей стране. Необходимо принимать во внимание то, что молодежь в Украине, по крайней мере, определенную ее часть, интересуют совсем другие вопросы по сравнению с теми, которые волнуют их сверстников в Британии или Соединенных Штатах.

Тема «безработица», например, до недавнего времени никогда не была горячей темой для нашей молодежи. В равной степени она не является слишком актуальной и в Британии, где эта проблема вследствие характер-

$$
-138-
$$


ного снижения рождаемости постепенно разрешилась. Анкетирования показали, что в конце 90-х годов поколение тинэйджеров, по крайней мере, в этом отношении, снова более «жизнерадостное», чем поколение их сверстников - тинэйджеров 80 -х годов.

То, что является чрезвычайно актуальным для молодежи в англоязычных странах, может не так интересовать молодежь в Украине. Это может привести к отсутствию интереса и непониманию.

Так как интересы студентов по различным причинам быстро могут меняться, мы должны искать такие области тем при планировании учебного плана, которые были бы важными для учащихся, отвечающими их жизненному опыту. Прежде всего, необходимо обратиться к такому фрагменту жизненного опыта, который имеют люди, вне зависимости от культурной и социальной специфики их стран, т. е. опыту в плане общечеловеческого бытия. Однако при введении таких тем в учебную программу, в планы практических занятий нужно быть уверенным в том, что основы жизненного (общечеловеческого) опыта у студентов уже есть.

Студент, изучающий иностранный язык, должен быть сориентирован, в первую очередь, на изучение тем, которые являются актуальными для познания и к которым он имеет доступ. Он также одновременно узнает, что между его собственным опытом и группой, на которую ориентирован материал по изучению англоязычной страны, есть различие. С одной стороны, есть «мост» между его миром и чужим миром, через который он попадает в чужой мир (преодоление порога незнакомых явлений). С другой стороны, у студента остается «напряжение частичного непонимания» (отдельных конкретных явлений, которые различаются в чужом мире), что является мотивацией для ведения своеобразной рекогносцировки в чужом мире. Поэтому ему предоставляется шанс сопоставить, установить, определить и соединить в процессе аллегорической символизации элементы, единства и структуры чужого мира с элементами, единствами и структурами собственного мира.

Это кажется более сложным, чем есть на самом деле. Педагогическая психология подсказывает нам, что прием новых элементов знаний и опыта только тогда возможен, когда они соотносятся с имеющимися в наличии и выпестованными в собственной культуре структурами знаний и опыта, что, в конечном счете, ведет к «расширению горизонтов» и дальше - к развитию личности учащегося.

Систематическая и сравнительная антропология давно занимается вопросами описания и классификации универсалий человеческого опыта бытия $[1 ; 3 ; 4]$.

К универсальному опыту бытия относится:

1) основной опыт бытия (рождение, смерть, существование (бытие) в миpe);

2) персональная идентичность (опыт «Я», персональные качества);

$$
-139-
$$


3) социальная идентичность в области личного (частное общение, например, семья: опыт «МЫ»);

4) социальная идентичность в области общественного (например, соседи, община, государство и т. д. - опыт «ОНИ»);

5) отношения между партнерами (дружба, любовь - опыт «ТЫ»);

6) жилище (дом, страна);

7) окружающая среда по ту сторону сферы личного (окружающий мир, природа, цивилизация и т. д.);

8) работа (обеспечение содержания);

9) воспитание (ориентировка в ценностях в общении);

10) обеспечение (пища, одежда и т. д.);

11) мобильность (ориентирование, транспорт и т. д.);

12) свобода/искусство (организация образа жизни);

13) коммуникация (пользование системой знаков средств массовой информации);

14) социальное обеспечение по здравоохранению (здоровье, болезнь, гигиена);

15) ориентировка в нормах и ценностях (этические принципы, религиозная ориентация и т. д.);

16) временно-исторический опыт (прошлое, современность, будущее);

17) духовные и душевные изменения (саморефлексия, сила воображения/фантазия, воспоминание, эмоции и т. д.).

Список неполон и очень абстрактен. Он только при первом впечатлении передает опыт «категорий поиска», которые могут играть роль для основного выбора тем. Его следует расширить и уточнить с учетом культурных и психофизиологических, характерных для этого возраста факторов. Определяя темы для урока английского языка как иностранного, следует учитывать, например, что для десятилетнего школьника тема «свободное времяпровождение» занимает иное место, нежели для шестнадцатилетнего, независимо от того, где он живет, или для украинского студента следует предлагать другие аспекты опыта/интересов, нежели для студента из иной страны.

Из этой дискуссии можно сделать отдельные выводы в отношении дидактики и методики урока английского языка:

1. В ориентированной на межкультурный контекст концепции урока области тем и аспекты тем должны привязываться к жизненному опыту соответствующей учебной группы и соединяться с репрезентативным жизненным опытом одногодков в стране изучаемого языка.

2. Чужой мир ни в классе, ни в непосредственном окружении не настоящий, хотя масс-медиа всегда используются на уроке. По этой причине должна развиваться дидактика понимания текстов для просмотра, прослушивания и прочтения (кино и телевидение или соответственно видео, аудиокассеты, компакт-диски, тематические тексты для чтения любого 
рода). Она должна совершенно сознательно включать в концепцию различия просмотра, прослушивания, прочтения, которые вытекают из относящихся к собственной культуре традиций и культурнопространственных расстояний.

3. Развитие способности выражения мнения на иностранном языке (говорение) должно не только опираться на диалогическую речь, но также на беседу по определенному вопросу/теме (дискуссия).

4. Развитие способности выражения мнения совершается не посредством чистого подражания утвержденному образцу диалога, но на основе процесса понимания, который всегда развивается перед выражением на иностранном языке. Дидактическая последовательность должна сообразно этому гласить: «от понимания иностранного языка к выражению». Развитие специфической дидактики понимания означает в первую очередь: развитие специфической дидактики чтения, поскольку текст для чтения как ранее, так и сейчас - и определенно длительное время - является основой урока иностранного языка.

5. В межкультурной концепции урока в отдаленных регионах изучаемого языка чтение охватывает не только виды текстов повседневной жизни (деловые тексты), но и художественные тексты. Литература в этой концепции имеет особенное значение.

6. Основополагающим методом межкультурного урока английского языка является сопоставление единств и структур отдельной культуры и целевой культуры. Он ясно включает сравнение языков.

7. Это сравнение, которое нормальным образом осуществляется в виде «немого процесса» в голове ученика, должно тематизироваться в уроке, т. е. разрешаться в речь. Это чрезвычайно важно для педагогического успеха урока, и об этом все время говорят, когда пытаются «расшифровать» новый текст или новое фото из чужого мира. На основании влияния собственной культуры строится картина чужого мира и посредством новой информации она изменяется или соответственно подтверждается; откуда и составляются мнения о странах изучаемого языка.

Согласно данной концепции нельзя строить урок английского языка как «курсы чтения». Предлагаемые на уроке тексты должны стать основой развития речевых умений и навыков. Нужно учить свободно говорить на иностранном языке. Ориентированные на целевую группу межкультурная дидактика и методика используют, следовательно, без «идеологических шор» элементы теории и принципы всех имеющихся учебных концепций, которые могут быть осмысленно включены во всеобъемлющую концепцию. Главное - отдельные тексты должны проверяться на целесообразность и применения. При этом необходимо отметить: не каждый аутентичный текст представляет чужой мир соответственным образом, не каждый текст одинаково хорош для урока иностранного языка и не каждый текст выполняет ту же самую дидактическую роль. Текст «сам по себе» является ценным только из-за того, что он аутентичен! Специально составленные

$$
-141-
$$


для учебника тексты имеют дидактическое значение при составлении учебной прогрессии.

Аутентичные тексты выполняют в своем собственном контексте определенные задания. Если в этом контексте они решаются и выполняются на уроке английского языка, то можно значительно усилить его функцию и эффект.

\section{Список использованной литературы}

1. Kohlberg, Lawrence. The Development of Children' Orientation Towards a Moral Order. Sequences in the Development of Moral Thought. - In: Vita Humana 6, 11 33, 1963.

2. Krusche, Dietrich. Annerkennung der Fremde - Thesen zur Konzeption regionaler Unterrichtswerke. - Jahrbuch Deutsch als Fremdsprache, Band 9, 248 - 258, 1983.

3. Murdoch, George P. The Common Denominator of Cultures. - In: Ralf Linton (ed.): The Science of Man in the World Crisis. - New York. Columbia University Press, 1945.

4. Rudolf, Wolfgang; Tschohl, Peter. Systimatische Anthropologie. - München. Iudicium, 1987.

5. Searle, John R. Speech Acts. - Cambridge University Press, 1969.

6. Stern, Hans H. Fundamental Concepts of Language Teaching. - Oxford University Press, 1984.

\section{Summary}

The article deals with the choice of topics and country studies material in the English language teaching process at junior courses of university philology departments. Some didactical methods concerning intercultural factors which should be taken into account are mentioned. 